\title{
A Case of Neurodegenerative Langerhans Cell Histiocytosis
}

Ana-Maria Petrica ${ }^{7}$ Nicolae-Ovidiu Gavrilovici' ${ }^{1}$ Doina Paula Pruteanu², Roxana Petean², Emilie Mihut ${ }^{2}$, Rodica Cosnarovici², Elena Diana Olteanu²

\begin{abstract}
Langerhans cell histiocytosis $(\mathrm{LCH})$ is a myeloproliferative neoplasm of pathologic dendritic cells, usually occurring in children. Clinical presentations of LCH vary from single lesions to life-threatening disseminated disease. There is a constant delay in reaching the diagnosis. This case report intends to bring clinicians up to date on the manifestations, diagnostic tools and treatment of this rare pathology while also highlighting the central nervous system involvement in $\mathrm{LCH}$.
\end{abstract}

Keywords: Langerhans cell histiocytosis, neurodegenerative LCH, ADHD, multisystemic LCH

\section{Rezumat}

Histiocitoza Langerhans este o boală mieloproliferativă a celulelor dendritice patologice, de obicei apărând la vârsta copilăriei. Prezentarea clinică a bolii variază de la leziuni singulare la boală diseminată ce pune viața în pericol. Există o întârziere constantă în punerea diagnosticului corect. Acest studiu de caz își propune să aducă clinicienii la zi cu privire la manifestările, metodele de diagnostic și tratament ale acestei boli rare, în timp ce subliniază exprimarea patologiei sistemului nervos central.

Cuvinte cheie: Histiocitoza cu celule Langerhans, LCH neurodegenerativă, ADHD, LCH multisistemică

\section{BACKGROUND}

Langerhans cell histiocytosis (LCH) is a myeloproliferative neoplasm of pathologic dendritic cells (DC). This is supported by the clonality of these cells, the recurrent mutations in BRAF-V600E and other MAPK pathway genes, the identification of the BRAF-V600E mutation in hematopoietic stem cells and myeloid precursors in patients with high-risk $\mathrm{LCH}^{1}$. An estimated 4-5 per million patients are affected each year, from the neonatal period to adulthood, although it appears to be more common in children of $0-15$ years $^{2,3}$.
Clinical presentations of LCH vary from single lesions to life-threatening disseminated disease. Even after years of clinical experience and numerous reported cases of LCH, there is a constant delay in reaching the diagnosis ${ }^{4}$. The reason lies in the multiple clinical presentations of the disease, corroborated with the failure to consider the diagnosis ${ }^{4,5}$.

Central nervous system (CNS) LCH is even harder to diagnose, the reported prevalence of LCH CNS involvement ranging widely from 3.4 to $57 \%$, mainly due to the lack of standard means of diagnosis. LCH CNS

\footnotetext{
1 "Iuliu Hatieganu" University of Medicine and Pharmacy, ClujNapoca, Romania

2 "Ion Chiricuta" Institute of Oncology, Cluj-Napoca, Romania

${ }^{3}$ Transilvania Medical Centre
}

\section{Corresponding author.}

Ana-Maria Petrica, „Iuliu Hatieganu" University of Medicine and Pharmacy, Cluj-Napoca, Romania.

E-mail: petrica_ana@yahoo.com 
disease can be divided into the following: (1) focal mass lesions and (2) lesions associated with progressive neurodegeneration patients ${ }^{1}$.

Here we present the diagnostic and treatment challenges of a case with CNS-LH and attention deficit disorder in the Romanian medical landscape. This case report intends to bring clinicians up to date on the manifestations, diagnostic tools and treatment of this rare pathology while also highlighting the central nervous system expression of LCH.

\section{CASE REPORT}

A 8-years-old patient with no relevant medical or family history was diagnosed and treated for a year with central diabetes insipidus in the Endocrinology Department (February 2015-March 2016), while also receiving treatment for attention deficit hyperactivity disorder (ADHD). As the disease progressed, exophthalmia added to the clinical manifestations. Langerhans Cell Histiocytosis was suspected. A periorbitary fat and inferior oblique muscle biopsy taken in March 2016 was inconclusive. However, the patient was referred to the Pediatric Oncology Department, where clinical examination also revealed skin lesions of the scalp, a biopsy of which confirmed the diagnosis of Langerhans Cell Histiocytosis.

The base line evaluation included: complete blood count; liver, renal function and electrolytes within normal range; brain MRI which revealed: orbital extrabulbar and retrobulbar infiltration, temporal cortical lesions, thickened optic chiasm, bilateral otomastoid and temporal petrous bone infiltration; a skeletal radiography and abdominal echography which did not detect other lesions (Figures 1,2,3).

The neurological evaluation: ADHD, polymorphic dyslalia, delay in speech and language acquisition, instrumental disturbances, impulsiveness, fixation and recall hypomnesia and a slight cognitive deficit.

The patient was diagnosed with Multisystemic Langerhans Cell Histiocytosis and treated according to the LCH III protocol (Metotrexat, Vinblastine, Mercaptopurine, Prednisone) (April 2016-Noevember 2017). The treatment was generally well tolerated (grade 1 anemia, grade 1 leucopenia), but the collaboration with the patient was difficult due to the attention deficit and hyperkinesis.

At the end of the treatment the brain MRI and bone scintigraphy revealed complete response.

In March 2018 during a follow-up, scalp skin lesions were detected and a biopsy was performed, but it did

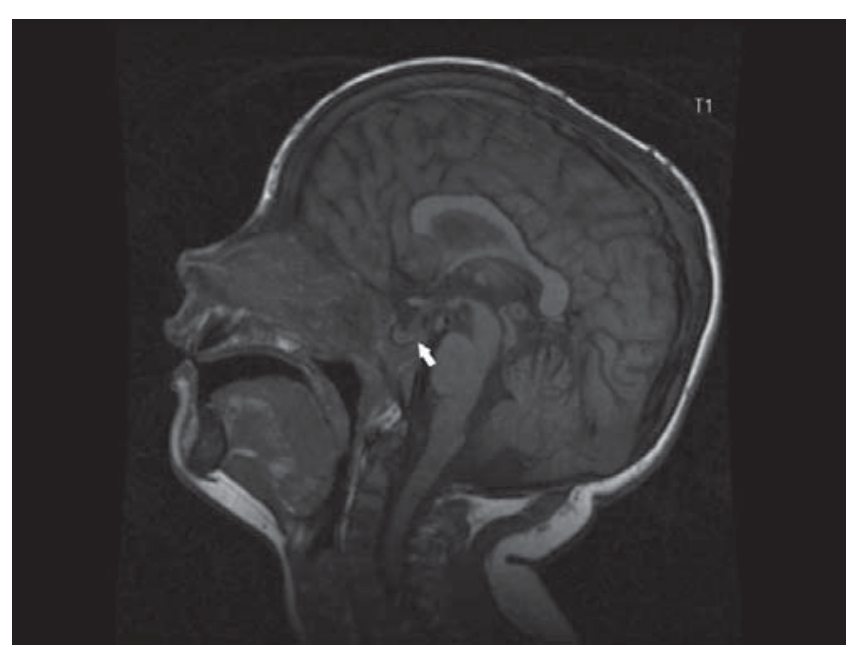

Figure 1. Cranio-cerebral MRI, sagital section, T1 weighted - thickening of the pituitary stalk with loss of the posterior pituitary bright spot.

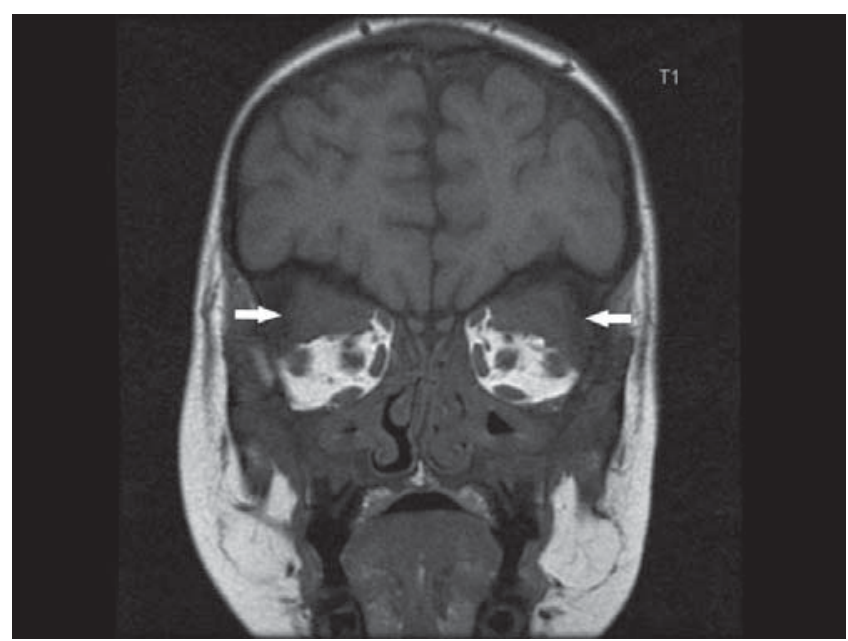

Figure 2. Cranio-cerebral MRI, coronal section, $\mathrm{T} 1$ weighted - bilateral supraorbitar masses.

not reveal signs of Histiocytosis. The neurological examination in March 2018 showed an improvement of the hyperkinetic disorder with attention deficit.

\section{DISCUSSION}

Once the diagnosis is made, the manifestations of the disease are easily understood and recognized. However, there is a high difficulty to suspect the diagnosis in the early phase, due to the many intricate and sometimes nonspecific symptoms. Consequently, there are many cases cited in the literature with relevant setbacks. Similar to our case, where there was a 1-year delay until the diagnosis, a prospective study concluded a time lag of $9.4 \pm 9.3$ mo. 15 out of 16 patients had been referred 


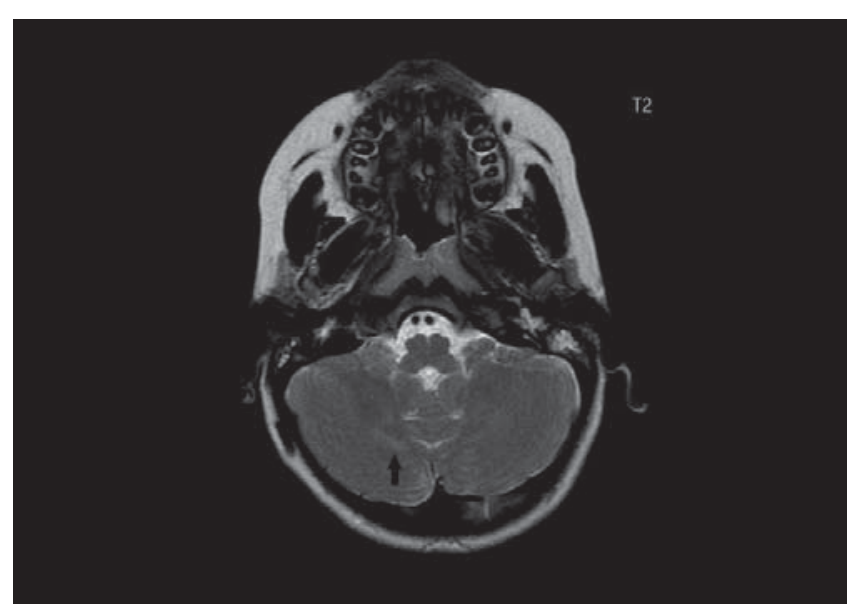

Figure 3. Cranio-cerebral MRI, axial section, T2 weighted - neurodegenerative lesion in the cerebellum.

with other diagnoses, after being treated symptomatically ${ }^{4}$.

Our patient had the following symptoms: DI, attention deficit hyperactivity disorder, exophthalmia and skin rash. Although a rare disease, the clinician should familiarize with the many manifestations of the disease, for the patient to benefit of timely diagnosis and treatment.

Most commonly affected are the bones, liver, spleen and lymph nodes. Other relevant manifestations of $\mathrm{LCH}$ are diabetes insipidus (DI) and common pediatric head and neck disorders, such as otitis media or skin rash $^{6}$. The clinician should be alert when simple complaints prove refractory to treatment, or in unusual head and neck findings ${ }^{7}$.

Endocrinologic manifestations of $\mathrm{LCH}$ are known to involve primarily the hypothalamic-pituitary region, with the clinical hallmark of $\mathrm{DI}^{8,9}$. DI has been an acknowledged manifestation of $\mathrm{LCH}$ for almost 30 years and can be revelatory for $\mathrm{LCH}$ and other severe conditions in children ${ }^{5,8,10-12}$. Differential diagnosis of the causes includes germinoma, craniopharyngioma, $\mathrm{LCH}$, local inflammatory, autoimmune, and vascular diseases, trauma, sarcoidosis, metastases, and cranial malformations, among which $\mathrm{LCH}$ is one of the most common ${ }^{13}$.

The orbit is the most common ophthalmologic site impaired, the superior or superolateral orbital roof being more interested ${ }^{14}$. The symptoms mirror the localization, size and infiltration of the lesion, with ptosis and/or swelling occurring if the anterior orbit is affected, proptosis in the posterior alterations, diplopia in muscle infiltration, nerve palsies and visual acuity due to amblyopia ${ }^{15}$.
Common skin manifestations are vesiculo-pustules, erythematous-brownish papules, ulcerous-crusty plaques, and a rash resembling recalcitrant seborrheic dermatitis, the last one being more erosive, ulcerative and frequent in MS-LCH ${ }^{14,16,17}$. When they regress, they leave behind hypochromia, atrophy, and alopecia. $\mathrm{LCH}$ can manifest with various and extensively investigated symptoms, diagnosed late, from a skin lesion ${ }^{16}$.

The mastoid bones may be involved, mimicking mastoiditis, and persistent middle ear disease can cause deafness from ossicle damage ${ }^{5}$.

Diabetes insipidus alone, and even more if associated with skin, ophthalmologic, or ENT pathologies, should arouse suspicion to the possibility of $\mathrm{LCH}^{18}$.

Central nervous system involvement is a long-term complication of LCH (CNS-LCH) ${ }^{19}$. CNS-risk lesions are defined as affections of the orbital, temporal, sphenoid, ethmoid or mastoid bones, the paranasal sinuses, the anterior or middle cranial fossa ${ }^{1,20,21}$. There is a high association of DI and neurodegenerative CNS (ND-CNS).

In our case, as many of the CNS-risk sites have been affected, the patient's cognitive symptoms could be interpreted as a sign of neurodegeneration - this is also supported by highly suggestive radiologic verdict.

Neurodegeneration is histologically characterized by the presence of CD8-positive T-lymphocyte infiltration, microglia activation, gliosis, neuronal and axonal destruction with secondary demyelination. Speculations on a triggering event include an infectious, paraneoplastic, immunological, autoimmune or metabolic process $^{22}$.

Cognitive changes include intellectual deficit and global cognitive impairment of attention capacities, episodic memory, verbal and non-verbal abilities ${ }^{23}$. Progression and severity of degeneration is variable ${ }^{24}$.

The ND-CNS can be assessed through MRI, FDGPET neuropsychological tools and genetic testing. As these evaluation methods have their limitations, an optimal diagnosis is still under discussion.

For our patient, MRI was used for assessment of CNS lesions. Gadolinium-enhanced brain MRI is currently considered the golden-standard imagistic examination for assessing these patients. Common imagistic discoveries include hypothalamic-pituitary involvement (thickening and enhancement of the pituitary stalk with loss of the posterior pituitary bright spot); enlargement and enhancement of the pineal gland or of the choroid plexus; intra-parenchymal masses; symmetric abnormalities of the dentate nuclei and of the 
white matter of the cerebellum and pons ${ }^{14}$. There was a lack of concordance between clinical and imagistic findings ${ }^{24}$. MRI identified lesions in patients at risk before neurological impairment and neurophysiological abnormalities became obvious ${ }^{20}$.

On fluoro-deoxyglucose-positron emission tomography (FDG-PET), lesions may show unusual FDG uptake $^{14}$. A study conducted by Ribeiro et al. (2008) concluded that FDG-PET may be helpful for the diagnosis of atypical cases and assessment of the disease's extent. While MRI may be normal or show only subtle and nonspecific abnormalities, FDG-PET could detect primitive lesions ${ }^{25}$.

Early stages of the disease could also be detected through neuropsychological tools, SEPs being the test with the highest capability to predict neurodegeneration $^{20}$.

BRAFV600E DNA was detected from the cerebrospinal fluid in rare cases, but all with active CNS lesions. When tested from peripheral mononuclear blood cells, it was shown to be more frequent in patients who developed ND-CNS, and it could therefore be used as a predictor ${ }^{21}$.

The combination of neurological, imagistic examination and SEPs has the highest diagnostic value for early diagnosis of neurodegeneration ${ }^{20,24}$. It is important that individuals affected by ND-CNS are diagnosed timely, in order to provide prompt support and to enter therapeutic trials, since effective cognitive reha- bilitative therapies have not been established yet for ND-CNS 22,23 .

Treatment for ND-CNS can include intravenous immunoglobulins, Vincristine/Cytosine Arabinoside, Cytosine Arabinoside ${ }^{26}$.

\section{CONCLUSION}

A few conclusions should be drawn from this case such that pediatricians should be familiar with the symptoms of LCH and have a high suspicion of the disease, for a timely referral to the oncologist. Being a rare pathology, the latter ought to report the cases further and collaborate with the Langerhans Cell Histiocytosis Society with the intent of development of diagnostic and therapeutic updated guides. Special attention should be given to the ND-CNS, which has to be thoroughly and immediately explored, if suspected. A specialized and multidisciplinary team is needed for the treatment of LCH.

\section{Compliance with ethics requirements:}

The authors declare no conflict of interest regarding this article.

The authors declare that all the procedures and experiments of this study respect the ethical standards in the Helsinki Declaration of 1975, as revised in 2008(5), as well as the national law. Informed consent was obtained from all the patients included in the study.

\section{References}

1. Yeh EA, Greenberg J, Abla O, Longoni G, Diamond E, Hermiston $\mathrm{M}$, et al. Evaluation and treatment of Langerhans cell histiocytosis patients with central nervous system abnormalities: Current views and new vistas. Pediatr Blood Cancer [Internet]. 2018 Jan [cited 2018 Aug 10];65(1):e26784. Available from: http://doi.wiley.com/10.1002/pbc.26784

2. Emile J-F, Abla O, Fraitag S, Horne A, Haroche J, Donadieu J, et al. Revised classification of histiocytoses and neoplasms of the macrophage-dendritic cell lineages. Blood [Internet]. 2016 Jun 2 [cited 2018 Aug 14];127(22):2672-81. Available from: http:// www.ncbi.nlm.nih.gov/pubmed/26966089

3. Windebank KP, Nanduri V. Langerhans Cell Histiocytosis. Arch Dis Child. 2009 May 19. [Medline].

4. Uppal P, Bothra M, Seth R, Iyer V, Kabra SK. Clinical Profile of Langerhans Cell Histiocytosis at a Tertiary Centre: A Prospective Study. Indian J Pediatr [Internet]. 2012 Nov 6 [cited 2018 Aug 10];79(11):1463-7. Available from: http://link.springer. com/10.1007/s12098-012-0719-7

5. Broadbent V, Egeler RM, Nesbit ME. Langerhans cell histiocytosis--clinical and epidemiological aspects. Br J Cancer Suppl

[Internet]. 1994 Sep [cited 2018 Aug 10];23:S11-6. Available from: http://www.ncbi.nlm.nih.gov/pubmed/8075001

6. Lewoczko KB, Rohman GT, LeSueur JR, Stocks RM, Thompson JW. Head and neck manifestations of langerhan's cell histiocytosis in children: A 46-year experience. Int J Pediatr Otorhinolaryngol [Internet]. 2014 Nov [cited 2018 Aug 9];78(11):1874-6. Available from: http://linkinghub.elsevier.com/retrieve/pii/ S0165587614004595

7. Levy J, Monos T, Kapelushnik J, Maor E, Nash M, Lifshitz T. Ophthalmic manifestations in Langerhans cell histiocytosis. Isr Med Assoc J [Internet]. 2004 Sep [cited 2018 Aug 10];6(9): 553-5. Available from: http://www.ncbi.nlm.nih.gov/pubmed/ 15373315

8. Soares ECS, Quidute ARP, Costa FWG, Gurgel MHC, Alves APNN, Fonteles CSR. Monostotic Langerhans' cell histiocytosis in a child with central diabetes insipidus. J Clin Pediatr Dent [Internet]. 2012 [cited 2018 Aug 9];36(4):377-81. Available from: http://www.ncbi.nlm.nih.gov/pubmed/23019836

9. Savardekar A, Tripathi M, Bansal D, Vaiphei K, Gupta SK. Isolated tumorous Langerhans cell histiocytosis of the brainstem: a 
diagnostic and therapeutic challenge. J Neurosurg Pediatr [Internet]. 2013 Sep [cited 2018 Aug 10];12(3):258-61. Available from: http://www.ncbi.nlm.nih.gov/pubmed/23848290

10. Dunger DB, Broadbent $\mathrm{V}$, Yeoman E, SeckI JR, Lightman SL, Grant DB, et al. The Frequency and Natural History of Diabetes Insipidus in Children with Langerhans-Cell Histiocytosis. N Engl J Med [Internet]. 1989 Oct 26 [cited 2018 Aug 9];321(17):115762. Available from: http://www.nejm.org/doi/abs/10.1056/ NEJM198910263211704

11. Windebank K, Nanduri V. Langerhans cell histiocytosis. Arch Dis Child 2009; 94: 904-908

12. Chen $X$, Huang $X$, Qiu $Y$, Chen $H, F u Y$, Li X. A case of thymic Langerhans cell histiocytosis with diabetes insipidus as the first presentation. Front Med [Internet]. 2013 Mar 28 [cited 2018 Aug 9];7(1):143-6. Available from: http://link.springer.com/10.1007/ s11684-013-0238-6

13. Wei S-T, Chen D-C, Cho D-Y, Lin H-L. Langerhans cell histiocytosis in monozygotic twins with central diabetes insipidus and hypophyseal masses. Asian J Neurosurg [Internet]. 2015 [cited 2018 Aug 10];10(2):105-7. Available from: http://www. ncbi.nlm.nih.gov/pubmed/25972939

14. Levy J, Monos T, Kapelushnik J, Maor E, Nash M, Lifshitz T. Ophthalmic manifestations in Langerhans cell histiocytosis. Isr Med Assoc J [Internet]. 2004 Sep [cited 2018 Aug 10];6(9):5535. Available from: http://www.ncbi.nlm.nih.gov/pubmed/ 15373315

15. Herwig MC, Wojno T, Zhang Q, Grossniklaus HE. Langerhans cell histiocytosis of the orbit: five clinicopathologic cases and review of the literature. Surv Ophthalmol [Internet]. 2013 [cited 2018 Aug 9];58(4):330-40. Available from: http://www.ncbi. nlm.nih.gov/pubmed/23246282

16. Bannach AB, Garcia MTFC, Soares DFG, Mattos AL de A, Barrese TZ, Abreu MAMM de. Langerhans' cell histiocytosis with neurological injuries diagnosed from a single cutaneous lesion. An Bras Dermatol [Internet]. 2017 [cited 2018 Aug 10];92(4):540-2. Available from: http://www.ncbi.nlm.nih.gov/ pubmed/28954107

17. Jezierska M, Stefanowicz J, Romanowicz G, Kosiak W, Lange M. Langerhans cell histiocytosis in children - a disease with many faces. Recent advances in pathogenesis, diagnostic examinations and treatment. Postep dermatologii i Alergol [Internet]. 2018 Feb [cited 2018 Aug 11];35(1):6-17. Available from: http:// www.ncbi.nlm.nih.gov/pubmed/29599667

18. Jarquin-Valdivia AA, Buchhalter J. Delayed Diagnosis of Pediatric Langerhans' Cell Histiocytosis: Case Report and Retrospective Review of Pediatric Cases Seen at Mayo Clinic. J Child Neurol [Internet]. 2001 Jul 2 [cited 2018 Aug 10];16(7):535-8. Available from: http://www.ncbi.nlm.nih.gov/pubmed/11453455
19. Jezierska M, Stefanowicz J, Romanowicz G, Kosiak W, Lange M. Langerhans cell histiocytosis in children - a disease with many faces. Recent advances in pathogenesis, diagnostic examinations and treatment. Postep dermatologii i Alergol [Internet]. 2018 Feb [cited 2018 Aug 11];35(1):6-17. Available from: http:// www.ncbi.nlm.nih.gov/pubmed/29599667

20. Sieni E, Barba C, Mortilla M, Savelli S, Grisotto L, Di Giacomo $G$, et al. Early Diagnosis and Monitoring of Neurodegenerative Langerhans Cell Histiocytosis. Herholz K, editor. PLoS One [Internet]. 2015 Jul 15 [cited 2018 Aug 10];10(7):e0131635. Available from: http://www.ncbi.nlm.nih.gov/pubmed/26176859

21. McClain KL, Picarsic J, Chakraborty R, Zinn D, Lin H, Abhyankar $\mathrm{H}$, et al. CNS Langerhans cell histiocytosis: Common hematopoietic origin for $\mathrm{LCH}$-associated neurodegeneration and mass lesions. Cancer [Internet]. 2018 Jun 15 [cited 2018 Sep 6];124(12):2607-20. Available from: http://doi.wiley.com/ $10.1002 /$ cncr.31348

21. Imashuku S, Arceci RJ. Strategies for the Prevention of Central Nervous System Complications in Patients with Langerhans Cell Histiocytosis. Hematol Oncol Clin North Am [Internet]. 2015 Oct [cited 2018 Aug 10];29(5):875-93. Available from: http:// linkinghub.elsevier.com/retrieve/pii/S0889858815000830

22. Grois N, Fahrner B, Arceci RJ, Henter J-I, McClain K, Lassmann $\mathrm{H}$, et al. Central Nervous System Disease in Langerhans Cell Histiocytosis. J Pediatr [Internet]. 2010 Jun [cited 2018 Aug 27];156(6):873-881.e1. Available from: https://linkinghub.elsevier.com/retrieve/pii/S0022347610002155

23. Le Guennec L, Decaix C, Donadieu J, Santiago-Ribeiro M, Martin-Duverneuil N, Levy R, et al. The cognitive spectrum in neurodegenerative Langerhans cell histiocytosis. J Neurol [Internet]. 2014 Aug 22 [cited 2018 Aug 10];261(8):1537-43. Available from: http://www.ncbi.nlm.nih.gov/pubmed/24848633

24. De La Hoz Polo M, Rebollo Polo M, Fons Estupiña C, Muchart López J, Cruz Martinez O. Neuroimagen de la histiocitosis de células de Langerhans en el sistema nervioso central pediátrico. Radiologia [Internet]. 2015 Mar [cited 2018 Aug 10];57(2):12330. Available from: http://linkinghub.elsevier.com/retrieve/pii/ S003383381400037X

25. Ribeiro M-J, Idbaih A, Thomas C, Remy P, Martin-Duverneuil N, Samson $Y$, et al. 18F-FDG PET in neurodegenerative Langerhans cell histiocytosis. J Neurol [Internet]. 2008 Apr 31 [cited 2018 Aug 11];255(4):575-80. Available from: http://link.springer.com/10.1007/s00415-008-0751-8

26. Allen CE, Flores R, Rauch R, Dauser R, Murray JC, Puccetti D, et al. Neurodegenerative central nervous system Langerhans cell histiocytosis and coincident hydrocephalus treated with vincristine/cytosine arabinoside. Pediatr Blood Cancer [Internet]. 2010 Mar [cited 2018 Sep 6];54(3):416-23. Available from: http://www.ncbi.nlm.nih.gov/pubmed/19908293 
